\title{
Blood parameters of sheep with high infection of Haemonchus contortus and treated with "mushroom of the sun" (Agaricus blazei)
}

\section{Parâmetros sanguíneos de ovinos com alta infecção por Haemonchus contortus e tratados com "cogumelo do sol" (Agaricus blazei)}

\author{
Gabriela Almeida Bastos ${ }^{1}$; Ana Cláudia Maia Soares ${ }^{1}$; Thallyta Maria Vieira²; \\ Renata Cristina de Souza Cândido ${ }^{3}$; Franciellen Morais-Costa ${ }^{4}$; Viviane de Oliveira \\ Vasconcelos $^{5}$; Neide Judith Faria Oliveira ${ }^{6}$; Eduardo Robson Duarte $6^{6 *}$
}

\begin{abstract}
Blood and parasitological parameters of sheep experimentally infected with Haemonchus contortus and treated with "mushroom of the sun" (Agaricus blazei) were assessed. Lambs infected with the nematode were divided into three groups: treated with basidiocarp powder from the fungus, wormed with trichlorfon, and a control group that did not receive anthelmintic. Split-plot design analysis was performed where the treatments were defined as plots and four periods of collection were defined as subplots. Interaction between the treatments and the collection periods for the fecal egg counts per gram of feces (FEC) was observed. Treatment with "mushroom of the sun" showed anthelmintic efficacies ranging from 28.6 to $54.2 \%$. Similar performances to weight gain were observed among the groups. A significant interaction between treatments and evaluation periods was observed for erythrocyte counts, hematocrit value, and serum concentrations of albumin and urea. The values of the mean corpuscular volume, erythrocyte distribution width, and leukocyte, neutrophil, lymphocyte, monocyte, and eosinophil counts, as well as the mean platelet volume, varied among the collection days. The administration of "mushroom of the sun" significantly reduced the FEC, did not influence on the erythrocyte count and hematocrit value, which remained within normal limits. However it increased the serum concentrations of albumin.
\end{abstract}

Key words: Agaricus blazei. Alternative control. Haemonchosis. Sheep. Blood profile.

\section{Resumo}

Avaliou-se os parâmetros sanguíneos e parasitológicos de ovinos infectados experimentalmente com Haemonchus contortus e tratados com "cogumelo do sol" (Agaricus blazei). Cordeiros infectados com o nematódeo foram distribuídos em três grupos: tratados com pó do basidiocarpo do fungo, vermifugados

1 Discentes de Mestrado do Curso de Pós-Graduação em Produção Animal, Instituto de Ciências Agrárias, Universidade Federal de Minas Gerais, UFMG, Montes Claros, MG, Brasil. E-mail: gabi_bastos@ymail.com; aninha_maiamoc@yahoo.com.br

2 Discente de Doutorado do Curso de Pós-Graduação em Parasitologia, Instituto de Ciências Biológicas, UFMG, Belo Horizonte, MG, Brasil. E-mail: thallytabio@gmail.com

3 Discente de Engenharia de Alimentos, Instituto de Ciências Agrárias, UFMG, Montes Claros, MG, Brasil. E-mail: renata.s.candido@hotmail.com

4 Pós-Doutoranda em Produção Animal, Instituto de Ciências Agrárias, UFMG, Montes Claros, MG, Brasil. E-mail: franmoraisbio@ gmail.com

5 Prof ${ }^{a}$ Efetiva, Universidade Estadual de Montes Claros, UNIMONTES, Montes Claros, MG, Brasil. E-mail: vivianevasconcelos27@gmail.com

6 Profs. Adjuntos, Instituto de Ciências Agrárias, UFMG, Montes Claros, MG, Brasil. E-mail: neidejudith@hotmail.com; duartevet@hotmail.com

* Author for correspondence 
com triclorfon e grupo controle, que não recebeu anti-helmíntico. Utilizou-se delineamento em parcelas subdivididas, sendo os tratamentos as parcelas e quatro períodos de coletas, as subparcelas. Verificouse interação dos tratamentos e dos períodos de coleta para o número de ovos por grama de fezes (OPG). O tratamento com "cogumelo do sol" apresentou eficácia anti-helmíntica variando de 28,6\% a $54,2 \%$, entretanto o desempenho foi semelhante entre os grupos. Verificou-se interação significativa dos tratamentos e os períodos avaliados para as contagens de eritrócitos, o valor do hematócrito e as concentrações séricas de albumina e ureia. Os valores do volume corpuscular médio, da amplitude de distribuição de eritrócitos, as contagens de leucócitos, neutrófilos, linfócitos, monócitos e eosinófilos, bem como o volume plaquetário médio variaram entre os dias de coleta. A administração do "cogumelo do sol" reduziu o OPG, não influenciou a contagem de eritrócitos e o valor do hematócrito, que estiveram dentro dos limites da normalidade, e aumentou significativamente as concentrações séricas de albumina.

Palavras-chave: Agaricus blazei. Controle alternativo. Haemoncose. Ovinos. Perfil sanguíneo.

\section{Introduction}

The health condition of animals can be evaluated by the determination of blood parameters. However, factors such as species, sex, age, physiological condition, time of the day, relative humidity, ambient temperature, and muscle activity can influence these parameters (LACERDA; SOTO-BLANCO, 2006).

Haemonchosis is caused by the Haemonchus contortus, the main gastrointestinal nematode (GN) in sheep, and, among the disease of small ruminants, it is responsible for high morbidity and mortality. This nematode is highly pathogenic promoting hematophagy and production of anticoagulant factors capable of inhibiting the formation of fibrin, inducing bleeding of the submucosal abomasum (NICOLODI et al., 2010). The treatment of helminthiasis in small ruminants is often performed exclusively with synthetic anthelmintics and in a non-rigorous way, thus, promoting the selection of resistant GN (SOCCOL et al., 1996). Therefore, organic production has been supported and alternatives for prevention and control using herbs and fungi have been the object of study (ALVES et al., 2001; HOLSBACK et al., 2013a).

Fungi produce anthelmintic substances and represent a promising alternative for the control of GN (ARAÚJO et al., 2007). The fungus Agaricus blazei, commonly known as "mushroom of the sun," contains several compounds with therapeutic and nutritional interest and it has been indicated in the complementary therapy of neoplasias and other alterations (DIAS et al., 2002; NOVAES et al., 2011). Although the mechanisms of action have not been elucidated yet, the bioactive substances in this mushroom have the ability to modulate the immune system (NOVAES et al., 2011).

The administration of the aqueous extract of this fungus also showed effects against Herpes Simplex type 1 (HSV-1) and Bovine Herpes type 1 (BoHV1) in HEp-2 cell culture. The extract showed a more effective virucidal than therapeutic activity for both viruses and a greater efficacy against the HSV-1 (BRUGGEMANN et al., 2006). In another study, mice infected with Leishmania amazonensis, L. chagasi, and L. major showed a significant reduction in the number of parasites in different organs. Moreover, no side effects were observed and an enhanced effectiveness was attained compared to those by conventional drugs such as amphotericin B (VALADARES et al., 2011). The aqueous extract of $A$. blazei was also effective in the control of Plasmodium berghei in experimentally infected mice, thus, representing an alternative for the treatment of malaria (VAL et al., 2015).

Little is known about the anthelmintic effect and the potential benefits of treatment with $A$. blazei in animals infected by GN. In this study, blood and parasitological parameters of sheep with a high infection of $H$. contortus and treated with "mushroom of the sun" were assessed. 


\section{Material and Methods}

The experimental work was performed at the Institute of Agricultural Sciences of the Federal University of Minas Gerais (ICA/UFMG), located in Montes Claros, a semiarid region in the state of Minas Gerais (latitude 16 $44^{\prime} 06^{\prime \prime} \mathrm{S}$ and longitude $\left.44^{\circ} 55^{\prime} 00^{\prime \prime}\right)$. All procedures were approved under the Protocol 42/2008 by the Ethics Committee on Animal Experimentation of the UFMG.

The studied sample comprised of 30 male crossbreed sheep of the breed Santa Ines, with an average body weight (BW) of $27.5 \mathrm{~kg}$ and previously wormed to present zero FEC. The animals were experimentally infected via oral uptake of 800 larvae of $H$. contortus per $10 \mathrm{~kg}$ BW. After twenty-one days, 15 animals with FEC greater than 3,000 were selected and suitably grouped in order to obtain homogeneous and high FEC average. The first group received $11.14 \mathrm{~g}$ of "mushroom of the sun" powder $\mathrm{kg}^{-1} \mathrm{BW}$ (based on dry matter $[\mathrm{DM}])$; the second was treated orally with $10 \mathrm{mg} \cdot \mathrm{kg}^{-1}$ of trichlorfon, and the third was not treated (control). Each group remained confined in stalls for a total of 45 days, including the 15-day period of adaptation. The experimental diet was balanced with a concentrate:voluminous ratio of 60:40 for an average daily weight gain of $200 \mathrm{~g}$, according to the National Research Council (NRC, 2007) guidelines. Food was provided at 08:00 AM and 04:00 PM, with water ad libitum.

Basidiocarps of the "mushroom of the sun" were produced organically and purchased at the "Mushroom of the North Producers Association of Minas and Vale do Jequitinhonha" (APROCONOVA), Brazil. The samples were ground in a mill and stored in dark paper bags at room temperature for two weeks to obtain the raw powder. The amount of DM was determined using subsamples dried at $105{ }^{\circ} \mathrm{C}$ to calculate the tested concentration as recommended by the Association of Official Analytical Chemists (AOAC, 1990).

The animals were housed in metabolic cages during the first three days of the experiment for administration of the fungus. After $12 \mathrm{~h}$ of fasting, $11.14 \mathrm{~g} \mathrm{DM} \mathrm{kg}^{-1} \mathrm{BW}$ were administered along with $12 \mathrm{~g} \cdot \mathrm{kg}^{-1} \mathrm{BW}$ of concentrate, on two consecutive days. On the third day of the experiment, after mushroom intake, the animals were re-housed in stalls. During the experimental period, the animals were inspected daily to check for possible changes in behavior, presence of submandibular swelling, weakness, and assessment of the ocular mucosa.

Parasitological collections, weighing of animals heavily infected with $H$. contortus, and blood tests were performed in the morning, after $12 \mathrm{~h}$ of fasting, on days $0,7,14$, and 21 , in the months of November and December. The animals' feces were collected after blood collection. Five to seven grams were directly obtained from the rectum of each animal and maintained at $5{ }^{\circ} \mathrm{C}$ for subsequent FEC. The mean value of FEC per animal was determined according to the technique described by Whitlock (1948), by using a saturated solution of sodium chloride and microscope readings with a $10 \times$ objective in two McMaster chambers for each sample. The efficacy of the products was estimated using the equation described by Coles et al. (1992):

$$
\text { Efficacy }=[1-(\text { FEC t } / \text { FEC c })] \times 100
$$

FEC $\mathrm{t}=$ average egg count per gram of feces for the group of treated animals. FEC $\mathrm{c}=$ average egg count per gram of feces for the control group.

Identification and confirmation of monoinfection by $H$. contortus was performed by coproculture (UENO, 1995); 100 third-stage larvae were identified from each animal, according to Keith's key (1953). After feces and blood collection, the sheep were also weighed for performance evaluation.

Blood samples were obtained from the jugular vein and collected in tubes containing ethylenediaminetetraacetic acid (EDTA) anticoagulant. The tubes were stored in isothermal containers with ice and sent to the Clinical Pathology Laboratory where the blood analysis 
were performed (BC 2.800 Vet, Mindray Medical International LTD, Shenzhen, China). Blood samples for biochemical dosages were collected in flasks without the anticoagulant. The determination of the serum concentrations of total protein, albumin, creatinine, and urea was performed using commercial kits (Bioclin, Quibasa Basic Chemistry Ltd., Belo Horizonte, MG, Brazil). The following techniques were used, respectively: biuret method, bromocresol green method, acidification with picric acid method, and colorimetric enzymatic method via urease and ammonia formation, which at alkaline $\mathrm{pH}$ and in the presence of salicylate and sodium hypochlorite, gives a greenish compound. The readings were obtained using a spectrophotometer (BIOPLUS BIO 2000). The total globulin concentrations were obtained from the difference between the concentrations of total protein and albumin (PAYNE; PAYNE, 1987).

The experiments were carried out in a split-plot arrangement with treatments defined as parcels and periods of collection as the subplots. FEC values were transformed into $\log _{10}(x+10)$ for statistical analysis. Analysis of variance of the data was carried out using the System for Statistical Analyses and Genetics (SAEG, 9.1). The mean values were compared using the Student-Newman-Keuls or Scott-Knott tests at 5\% probability, following Sampaio (2007).

\section{Results}

The animals treated with "mushroom of the sun" showed good acceptance of the product, and no behavioral changes were observed during the experiment. Interaction between the treatments and the collection periods for assessment of the FEC was observed (Table 1). The FEC average of sheep treated with "mushroom of the sun" was significantly lower than that of untreated sheep after seven days of treatment. The use of trichlorfon induced a significant and effective reduction of FEC averege after the same period. The treatments did not influence the body weight of lambs and 21 days after treatments, the BW averages were higher than other periods ( $\mathrm{p}<0.05$, Table 2$)$.

Table 1. Mean fecal egg count (FEC) of Haemonchus contortus before and after post-treatment with the dry powder Agaricus blazei (11.14 g/g bw) or triclorfon (10 mg/g bw).

\begin{tabular}{llllllll}
\hline \multirow{2}{*}{ Treatment } & Before treatment & \multicolumn{2}{c}{ One week } & \multicolumn{2}{c}{ Two week } & \multicolumn{2}{c}{ Three week } \\
& FEC & FEC & $\%^{*}$ & FEC & $\%^{*}$ & FEC & $\% *$ \\
\hline A.blazei & $3.127 \mathrm{Aa}$ & $2.223 \mathrm{Cb}$ & 28.6 & $2.1 \mathrm{Cb}$ & 54.2 & $3.020 \mathrm{Bb}$ & 33.3 \\
Triclorfon & $3.054 \mathrm{Aa}$ & $6.66 \mathrm{Bc}$ & 99.8 & $0.0 \mathrm{Cc}$ & 100.0 & $0.000 \mathrm{Cc}$ & 100.0 \\
Untreat & $3.325 \mathrm{Ca}$ & $3.113 \mathrm{Da}$ & & $4.6 \mathrm{Aa}$ & & $4.530 \mathrm{Ba}$ & \\
\hline
\end{tabular}

Lowercase letters in columns and capital letters in rows indicate significant differences $(\mathrm{P} \leq 0.05$ in Scott-Knott test).

$* \%$ efficacy $=100 \times(1-$ mean of L1/ mean eggs + L1 $)$.

A significant interaction was observed between the treatments and collection periods for red blood cell counts and hematocrit values. A lower mean corpuscular volume and reduced relative amplitude of erythrocyte distribution were found on days 7 and 14 and on days 7, 14, and 21, respectively (Table 3). On the twenty-first day, sheep treated with trichlorfon showed increased number of erythrocytes and hematocrit value than other groups. However, all the average values were found within the normal range for the species (Table 3). The lambs were physically healthy, showing no signs of submandibular edema, weakness, or inappetence, and a Famacha $^{\odot}$ score between one and two was observed for the ocular mucosa. 
Table 2. Average values weight of sheep of haemonchosis treated with dry power Agaricus blazei (11.14 g/g bw) or triclorfon $(10 \mathrm{mg} / \mathrm{g} \mathrm{bw})$ and untreated animals at different periods.

\begin{tabular}{lcccc}
\hline Treatment & Zero day & One week & Two week & Three week \\
\hline A.blazei & $25.30 \mathrm{a}$ & $25.12 \mathrm{a}$ & $25.82 \mathrm{a}$ & $26.36 \mathrm{a}$ \\
Triclorfon & $29.60 \mathrm{a}$ & $29.40 \mathrm{a}$ & $29.46 \mathrm{a}$ & $30.14 \mathrm{a}$ \\
Untreat & $28.40 \mathrm{a}$ & $28.26 \mathrm{a}$ & $27.90 \mathrm{a}$ & $28.24 \mathrm{a}$ \\
*Interaction period & $27.58 \mathrm{~B}$ & $27.62 \mathrm{~B}$ & $27.72 \mathrm{~B}$ & $28.24 \mathrm{~A}$ \\
\hline
\end{tabular}

Lowercase letters in columns and capital letters in rows indicate significant differences ( $\mathrm{P} \leq 0.05$ in Student-Newman-Keuls (SNK) test).

Table 3. Mean values of erythrocytes, hemoglobin, hematocrit, mean corpuscular hemoglobin concentration, corpuscular hemoglobin concentration, mean corpuscular volume and amplitude distribution of erythrocytes in sheep with haemonchosis treated with Agaricus blazei (11.14 g/g bw) or triclorfon (10 mg/g bw) and untreated animals at different periods.

\begin{tabular}{|c|c|c|c|c|c|}
\hline Treatment & Zero day & One week & Two week & Three week & Reference $^{\mathrm{a}}$ \\
\hline \multicolumn{6}{|c|}{ Erythrocytes $\left(\times 10^{6} / \mu \mathrm{L}\right)$} \\
\hline A. blazei & $11.46 \mathrm{Aa}$ & $11.28 \mathrm{Aa}$ & $10.93 \mathrm{Aa}$ & $11.45 \mathrm{Ab}$ & \\
\hline Triclorfon & $10.68 \mathrm{Ba}$ & $11.21 \mathrm{Ba}$ & $11.68 \mathrm{Ba}$ & $12.82 \mathrm{Aa}$ & $9-15$ \\
\hline Untreated & $10.29 \mathrm{Ba}$ & $11.96 \mathrm{ABa}$ & $11.25 \mathrm{ABa}$ & $11.52 \mathrm{ABb}$ & \\
\hline \multicolumn{6}{|c|}{ Hemoglobin $(\mathrm{g} / \mathrm{dL})$} \\
\hline A.blazei & $10.38 \mathrm{Aa}$ & $10.20 \mathrm{Aa}$ & $09.22 \mathrm{Aa}$ & $10.60 \mathrm{Aa}$ & \\
\hline Triclorfon & $10.02 \mathrm{Aa}$ & $10.74 \mathrm{Aa}$ & $10.82 \mathrm{Aa}$ & $12.20 \mathrm{Aa}$ & $9-15$ \\
\hline Untreated & $10.26 \mathrm{Aa}$ & $10.98 \mathrm{Aa}$ & $10.44 \mathrm{Aa}$ & $11.08 \mathrm{Aa}$ & \\
\hline \multicolumn{6}{|c|}{ Hematocrit (\%) } \\
\hline A.blazei & $32.20 \mathrm{Aa}$ & $30.28 \mathrm{Aa}$ & $30.00 \mathrm{Aa}$ & $32.68 \mathrm{Ab}$ & \\
\hline Triclorfon & $30.56 \mathrm{Ba}$ & $31.72 \mathrm{Ba}$ & $33.42 \mathrm{Ba}$ & $37.24 \mathrm{Aa}$ & $27-45$ \\
\hline Untreated & $29.16 \mathrm{Ba}$ & $33.00 \mathrm{ABa}$ & $31.48 \mathrm{ABa}$ & $33.28 \mathrm{ABb}$ & \\
\hline \multicolumn{6}{|c|}{ Corpuscular hemoglobin concentration $(\mathrm{pg})$} \\
\hline A.blazei & $9.06 \mathrm{Aa}$ & $9.00 \mathrm{Aa}$ & $8.98 \mathrm{Aa}$ & $9.26 \mathrm{Aa}$ & \\
\hline Triclorfon & $9.36 \mathrm{Aa}$ & $9.56 \mathrm{Aa}$ & $9.24 \mathrm{Aa}$ & $9.51 \mathrm{Aa}$ & $8-12$ \\
\hline Untreated & $11.76 \mathrm{Aa}$ & $9.12 \mathrm{Aa}$ & $9.28 \mathrm{Aa}$ & $9.60 \mathrm{Aa}$ & \\
\hline \multicolumn{6}{|c|}{ Mean corpuscular hemoglobin concentration $(\mathrm{g} / \mathrm{l})$} \\
\hline A. blazei & $32.30 \mathrm{Aa}$ & $33.64 \mathrm{Aa}$ & $32.92 \mathrm{Aa}$ & $32.28 \mathrm{Aa}$ & \\
\hline Triclorfon & $32.76 \mathrm{Aa}$ & $33.86 \mathrm{Aa}$ & $32.38 \mathrm{Aa}$ & $33.80 \mathrm{Aa}$ & $31-34$ \\
\hline Untreated & $33.02 \mathrm{Aa}$ & $33.28 \mathrm{Aa}$ & $33.16 \mathrm{Aa}$ & $33.28 \mathrm{Aa}$ & \\
\hline \multicolumn{6}{|c|}{ Mean corpuscular volume(fl) } \\
\hline A.blazei & $28.16 \mathrm{a}$ & $26.96 \mathrm{a}$ & $27.56 \mathrm{a}$ & $28.72 \mathrm{a}$ & \\
\hline Triclorfon & $28.86 \mathrm{a}$ & $28.52 \mathrm{a}$ & $28.80 \mathrm{a}$ & $29.24 \mathrm{a}$ & $28-40$ \\
\hline Untreated & $28.99 \mathrm{a}$ & $27.62 \mathrm{a}$ & $28.10 \mathrm{a}$ & $28.96 \mathrm{a}$ & \\
\hline Interaction period & $28.97 \mathrm{~A}$ & $27.69 \mathrm{~B}$ & $28.15 \mathrm{~B}$ & $28.97 \mathrm{~A}$ & \\
\hline \multicolumn{6}{|c|}{ Amplitude distribution erythrocytes (\%) } \\
\hline A.blazei & $17.54 \mathrm{a}$ & $18.14 \mathrm{a}$ & $18.36 \mathrm{a}$ & $19.72 \mathrm{a}$ & \\
\hline Triclorfon & $17.50 \mathrm{a}$ & $18.12 \mathrm{a}$ & $18.22 \mathrm{a}$ & $18.31 \mathrm{a}$ & $*$ \\
\hline Untreated & $18.40 \mathrm{a}$ & $18.94 \mathrm{a}$ & $19.28 \mathrm{a}$ & $19.66 \mathrm{a}$ & \\
\hline Interaction period & $17.81 \mathrm{C}$ & $18.40 \mathrm{~B}$ & 18. $62 \mathrm{~B}$ & $19.23 \mathrm{~A}$ & \\
\hline
\end{tabular}

Lowercase letters in columns and capital letters in rows indicate significant differences ( $\mathrm{P} \leq 0.05$ in Student-Newman-Keuls (SNK) test). ${ }^{a}$ Reference range for healthy sheep (PUGH, 2004). "Not found in the literature. 
A significant difference was observed between the assessment periods for total leukocyte, neutrophil, lymphocyte, monocyte, and eosinophil counts (Table 4). The mean leukocyte count was greater on day zero and the neutrophil count decreased on days 14 and 21 post-treatment $(\mathrm{p}<0.05)$ for both lamb groups. Despite all the average values being within the reference limits, lymphocyte average values were significantly higher at days zero and 14 (Table 4). The monocyte and eosinophil average counts were greater on day $7(\mathrm{p}<0.05)$ (Table 4). The mean values of basophils did not change with the treatment or evaluation periods, ranging from 0 to $0.042 / \mu \mathrm{L}$. The thrombograms were similar ( $p$ $>0.05$ ) among the treatments and the assessment periods, with the plateletcrit average values ranging from 0.162 to $0.227 \%$ (Table 5).

Table 4. Mean values for leukocytes, neutrophils, lymphocytes, monocytes and eosinophils in sheep with haemonchosis treated with Agaricus blazei (11.14 g/g bw) or triclorfon $(10 \mathrm{mg} / \mathrm{g} \mathrm{bw})$ and untreated animals at different periods.

\begin{tabular}{|c|c|c|c|c|c|}
\hline Treatment & Zero day & One week & Two week & Three week & Reference $^{a}$ \\
\hline \multicolumn{6}{|c|}{ Leukocytes $(\mu \mathrm{L})$} \\
\hline A. blazei & $8.900 \mathrm{a}$ & $8.520 \mathrm{a}$ & $8.140 \mathrm{a}$ & $6.940 \mathrm{a}$ & \multirow{4}{*}{$4.000-12000$} \\
\hline Triclorfon & $10.100 \mathrm{a}$ & $8.580 \mathrm{a}$ & $8.860 \mathrm{a}$ & $8.260 \mathrm{a}$ & \\
\hline Untreated & $8.460 \mathrm{a}$ & $7.200 \mathrm{a}$ & $6.560 \mathrm{a}$ & $6.460 \mathrm{a}$ & \\
\hline \multirow[t]{2}{*}{ Interaction Period ${ }^{\mathrm{b}}$} & $9.150 \mathrm{~A}$ & $8.100 \mathrm{~B}$ & $7.850 \mathrm{~B}$ & $7.200 \mathrm{~B}$ & \\
\hline & & \multicolumn{3}{|c|}{ Lymphocytes $(\mu \mathrm{L})$} & \multirow{5}{*}{$2.000-9.000$} \\
\hline A. blazei & $4.702 \mathrm{a}$ & $4.211 \mathrm{a}$ & $4.983 \mathrm{a}$ & $4.732 \mathrm{a}$ & \\
\hline Triclorfon & $5.408 \mathrm{a}$ & $3.879 \mathrm{a}$ & $6.163 \mathrm{a}$ & $4.861 \mathrm{a}$ & \\
\hline Untreated & $4.144 \mathrm{a}$ & $3.816 \mathrm{a}$ & $4.005 \mathrm{a}$ & $3.621 \mathrm{a}$ & \\
\hline \multirow{2}{*}{ Interaction Period ${ }^{b}$} & $4.750 \mathrm{~A}$ & $3.960 \mathrm{~B}$ & $5.050 \mathrm{~A}$ & $4.280 \mathrm{~B}$ & \\
\hline & & \multicolumn{2}{|c|}{ Neutrophils $(\mu \mathrm{L})$} & & \multirow{5}{*}{$700-6.000$} \\
\hline A. blazei & $3.956 \mathrm{Aa}$ & $3.614 \mathrm{Aa}$ & $2.932 \mathrm{Aa}$ & $2.431 \mathrm{Aa}$ & \\
\hline Triclorfon & $4.618 \mathrm{Aa}$ & $4.150 \mathrm{Aa}$ & $2.527 \mathrm{Aa}$ & $3.202 \mathrm{Aa}$ & \\
\hline Untreated & 4.231 Aa & $3.005 \mathrm{Aa}$ & $2.407 \mathrm{Aa}$ & $2.730 \mathrm{Aa}$ & \\
\hline \multirow[t]{2}{*}{ Interaction period ${ }^{\mathrm{b}}$} & $4.260 \mathrm{~A}$ & $3.590 \mathrm{~B}$ & $2.620 \mathrm{C}$ & $2.708 \mathrm{C}$ & \\
\hline & & \multicolumn{2}{|c|}{ Monocytes $(\mu \mathrm{L})$} & & \\
\hline A. blazei & $0.051 \mathrm{a}$ & $0.284 \mathrm{a}$ & $0.000 \mathrm{a}$ & $0.012 \mathrm{a}$ & \\
\hline Triclorfon & $0.000 \mathrm{a}$ & $0.310 \mathrm{a}$ & $0.019 \mathrm{a}$ & $0.000 \mathrm{a}$ & $0-750$ \\
\hline Untreated & $0.006 \mathrm{a}$ & $0.124 \mathrm{a}$ & $0.019 \mathrm{a}$ & $0.000 \mathrm{a}$ & \\
\hline \multirow[t]{2}{*}{ Interaction Period ${ }^{\mathrm{b}}$} & $0.019 \mathrm{~B}$ & $0.239 \mathrm{~A}$ & $0.013 \mathrm{~B}$ & $0.004 \mathrm{~B}$ & \\
\hline & & \multicolumn{2}{|c|}{ Eosinophils $(\mu \mathrm{L})$} & & \\
\hline A. Blazei & $0.166 \mathrm{a}$ & $0.372 \mathrm{a}$ & $0.202 \mathrm{a}$ & $0.134 \mathrm{a}$ & \\
\hline Triclorfon & $0.071 \mathrm{a}$ & $0.119 \mathrm{a}$ & $0.147 \mathrm{a}$ & $0.187 \mathrm{a}$ & $0-1000$ \\
\hline Untreated & $0.098 \mathrm{a}$ & $0.246 \mathrm{a}$ & $0.125 \mathrm{a}$ & $0.082 \mathrm{a}$ & \\
\hline Interaction period ${ }^{\mathrm{b}}$ & $0.112 \mathrm{~B}$ & $0.272 \mathrm{~A}$ & $0.158 \mathrm{~B}$ & $0.134 \mathrm{~B}$ & \\
\hline
\end{tabular}

Lowercase letters in columns and capital letters in rows indicate significant differences $(\mathrm{P} \leq 0,05$ in Student-Newman-Keuls (SNK)

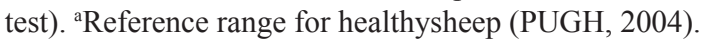

Animals treated with trichlorfon and "mushroom of the sun" showed progressive recovery of albumin concentration, returning to the baseline level after 21 days, unlike that in the control group (Table 6). The concentrations of serum creatinine were similar between treatments and evaluation periods. The serum urea concentrations significantly increased in the group treated with "mushroom of the sun" after the sixth day (Table 6). 
Table 5. Mean value of platelet, amplitude distribution of platelet and mean platelet volume of sheep with haemonchosis treated with Agaricus blazei (11.14 g/g bw) or triclorfon $(10 \mathrm{mg} / \mathrm{g} \mathrm{bw})$ and untreated animals at different times.

\begin{tabular}{|c|c|c|c|c|}
\hline Treatment & Zero day & One week & Two week & Three week \\
\hline \multicolumn{5}{|c|}{ Platelet $\left(10^{3}\right) / \mu \mathrm{L}$} \\
\hline A.blazei & $520.52 \mathrm{Aa}$ & $537.00 \mathrm{Aa}$ & $475.60 \mathrm{Aa}$ & $483.80 \mathrm{Aa}$ \\
\hline Triclorfon & $501.12 \mathrm{Aa}$ & $420.20 \mathrm{Aa}$ & $464.40 \mathrm{Aa}$ & $458.80 \mathrm{Aa}$ \\
\hline Untreated & $475.30 \mathrm{Aa}$ & $492.00 \mathrm{Aa}$ & $586.00 \mathrm{Aa}$ & $510.00 \mathrm{Aa}$ \\
\hline \multicolumn{5}{|c|}{ Amplitude distribution platelet (\%) } \\
\hline A.blazei & 14.96 Aa & $14.88 \mathrm{Aa}$ & 14.94 Aa & $14.94 \mathrm{Aa}$ \\
\hline Triclorfon & $15.08 \mathrm{Aa}$ & $15.02 \mathrm{Aa}$ & $15.00 \mathrm{Aa}$ & $15.04 \mathrm{Aa}$ \\
\hline Untreated & $14.84 \mathrm{Aa}$ & $14.94 \mathrm{Aa}$ & $14.80 \mathrm{Aa}$ & $14.86 \mathrm{Aa}$ \\
\hline \multicolumn{5}{|c|}{ Mean platelet volume (fl) } \\
\hline A.blazei & $3.94 \mathrm{Aa}$ & $3.82 \mathrm{Aa}$ & $3.80 \mathrm{Aa}$ & $3.98 \mathrm{Aa}$ \\
\hline Triclorfon & $3.50 \mathrm{Aa}$ & $3.88 \mathrm{Aa}$ & $3.88 \mathrm{Aa}$ & $3.92 \mathrm{Aa}$ \\
\hline Untreated & $3.77 \mathrm{Aa}$ & $3.88 \mathrm{Aa}$ & $3.88 \mathrm{Aa}$ & $3.90 \mathrm{Aa}$ \\
\hline
\end{tabular}

Lowercase letters in columns and capital letters in rows indicate significant differences ( $\mathrm{P} \leq 0.05$ in Student-Newman-Keuls (SNK) test.

Table 6. Mean value of protein , albumin, globulin, urea and creatinine to sheep treated with Agaricus blazei (11.14 $\mathrm{g} / \mathrm{g} \mathrm{bw})$ or triclorfon $(10 \mathrm{mg} / \mathrm{g} \mathrm{bw})$ and untreated animals at different periods.

\begin{tabular}{|c|c|c|c|c|c|}
\hline Treatment & Zero day & One week & Two week & Three week & Reference $^{a}$ \\
\hline & & Protein $(\mathrm{g} / \mathrm{dL})$ & & & \\
\hline A.blazei & $6.010 \mathrm{Aa}$ & $6.027 \mathrm{Aa}$ & $6.027 \mathrm{Aa}$ & $6.214 \mathrm{Aa}$ & \\
\hline Triclorfon & $6.654 \mathrm{Aa}$ & $5.820 \mathrm{Aa}$ & $6.312 \mathrm{Aa}$ & $6.072 \mathrm{Aa}$ & $6-7.9$ \\
\hline \multirow[t]{2}{*}{ Untreated } & $6.514 \mathrm{Aa}$ & $6.284 \mathrm{Aa}$ & $6.352 \mathrm{Aa}$ & $6.338 \mathrm{Aa}$ & \\
\hline & & Albumin (g/dL) & & & \\
\hline A.blazei & $1.88 \mathrm{Cb}$ & $1.74 \mathrm{Da}$ & $2.19 \mathrm{Ba}$ & $2.41 \mathrm{Ab}$ & \\
\hline Triclorfon & $1.09 \mathrm{Db}$ & $1.11 \mathrm{Cb}$ & $2.19 \mathrm{Ba}$ & $2.55 \mathrm{Aa}$ & $2.4-3$ \\
\hline \multirow[t]{2}{*}{ Untreated } & $2.92 \mathrm{Aa}$ & $1.99 \mathrm{Ba}$ & $1.85 \mathrm{Cb}$ & $1.58 \mathrm{Dc}$ & \\
\hline & & Globulin (g/dL) & & & \\
\hline A.blazei & $4.106 \mathrm{Aa}$ & $4.021 \mathrm{Aa}$ & $3.837 \mathrm{Aa}$ & $3.806 \mathrm{Aa}$ & \\
\hline Triclorfon & $5.565 \mathrm{Aa}$ & $4.708 \mathrm{Aa}$ & $4.123 \mathrm{Aa}$ & $3.521 \mathrm{Aa}$ & $3.50-5.70$ \\
\hline \multirow[t]{2}{*}{ Untreated } & $3.592 \mathrm{Aa}$ & $4.294 \mathrm{Aa}$ & $4.506 \mathrm{Aa}$ & $4.763 \mathrm{Aa}$ & \\
\hline & & Urea (mg/dL) & & & \\
\hline A. blazei & $27.00 \mathrm{Ca}$ & $21.00 \mathrm{Da}$ & $29.80 \mathrm{Aa}$ & $28.60 \mathrm{Ba}$ & \\
\hline Triclorfon & $15.40 \mathrm{Db}$ & $23.40 \mathrm{Ca}$ & $26.40 \mathrm{Ab}$ & $23.80 \mathrm{Bb}$ & $17-42.8$ \\
\hline \multirow[t]{2}{*}{ Untreated } & $14.00 \mathrm{Db}$ & $26.00 \mathrm{Aa}$ & $19.60 \mathrm{Bc}$ & $16.80 \mathrm{Cc}$ & \\
\hline & & Creatinine $(\mathrm{mg} / \mathrm{dL})$ & & & \\
\hline A. blazei & $0.985 \mathrm{Aa}$ & $0.837 \mathrm{Aa}$ & $1.118 \mathrm{Aa}$ & $1.014 \mathrm{Aa}$ & \\
\hline Triclorfon & $1.085 \mathrm{Aa}$ & $1.016 \mathrm{Aa}$ & $0.987 \mathrm{Aa}$ & $1.079 \mathrm{Aa}$ & $1.2-1.9$ \\
\hline Untread & $1.063 \mathrm{Aa}$ & $1.022 \mathrm{Aa}$ & $0.941 \mathrm{Aa}$ & $0.985 \mathrm{Aa}$ & \\
\hline
\end{tabular}

Lowercase letters in columns and capital letters in rows indicate significant differences $(\mathrm{P} \leq 0,05)$ in Scott-Knott test. ${ }^{a}$ Reference range for healthysheep (PUGH, 2004). 


\section{Discussion}

Control of haemonchosis in small ruminants is performed with anthelmintic drugs, thus, favoring the selection of resistant nematodes and possible accumulation of residues in the food and environment. Therefore, alternative treatments have been continuously investigated (SOCCOL et al., 1996, HOLSBACK et al., 2013a). In this study, we observed a significant reduction (up to $54.2 \%$ efficacy) of FEC in animals treated with A. blazei. In an in vivo study where fungi were used in the sheep diet, Alves et al. (2003) reported an efficacy of $88.8 \%$ in the reduction of FEC in animals treated with $20 \mathrm{~g}$ of Monacrosporium thaumasia, twice a week. Weekly doses of 2 to $2.5 \mathrm{~g}$ of mycelia from this fungus were effective in reducing the FEC number and resulted in greater BW gain than that in other groups (ARAÚJO et al., 2007). These results indicate that the use of fungi in controlling haemonchosis might be a promising alternative, contributing to a reduction of worming with recourse to synthetic products.

In this study, the animals received diets designed to promote BW gains greater than $200 \mathrm{~g}$ per day. Thus, possible changes caused by haemonchosis were attenuated and did not promote significant clinical changes in blood parameters during the assessment period. Appropriate diets can reduce the pathogenesis of $H$. contortus, since high levels of protein can improve tolerance to the adverse consequences of parasitism (MOLENTO et al., 2013).

The erythrocyte count was found to be within normal values (PUGH, 2004) despite the high initial FEC number. The average was greater at 21 days after worming with trichlorfon (Table 3). The increase in the number of erythrocytes in this group is possibly related to lower blood spoliation by the seventh day, since the drug has high anthelmintic efficacy (99.8 to $100 \%)$.

Sheep infected with $H$. contortus can lose onefifth of the total volume of circulating erythrocytes per day, with the resultant pathogenic effects being associated to the host's inability to compensate for this spoliation. Among the main factors that can assist the response to parasitosis is balanced nutrition (BOWMAN, 2010).

The average hematocrit was found to be within the normal range for sheep. This parameter indicates the degree of anemia of the animal, being important for assessing hematophagous parasites (SOTOMAIOR et al., 2007). In cases of acute haemonchosis, anemia is characterized by a continuous reduction of the hematocrit, and values below $15 \%$ are concomitant with weakness, indicating a bad prognosis (BOWMAN, 2010). In another study of sheep infected with the nematode, Costa et al. (2011) reported normal hematocrit values (24.7 to $29.6 \%$ ) in untreated animals or treated with anthelmintics. The mean corpuscular volume indicates the size of the red blood cells, often enhanced in cases of anemia, providing an early indication of the volume change of the erythrocytes (HARVEY, 2012). The values obtained in the present study were found to be within the normal range for sheep.

The average leukocyte count was significantly high on day zero for both treatment groups, which could be justified by abomasitis caused by $H$. contortus. The animals had already been infected for 21 days before the beginning of the experiments, thus, corresponding to the acute phase of haemonchosis. The results of the leukogram were all within the reference values for sheep. In wellfed animals and in animals with greater resistance to worms, a reduction or elimination of nematodes may occur, thus, explaining the observation of leukogram values within the normal range (AMARANTE; SALES, 2007). Parasitized sheep treated with the immunostimulants Propionibacterium granulosum and Escherichia coli lipopolysaccharide combined with albendazole anthelmintic resulted in neutrophil mean values ranging from 8.166 to $9.640 / \mu \mathrm{L}$ (MARTINS et al., 2012). These values are higher than those obtained in the present study. Birgel et al. (2012) reported that aggravation of anemia 
symptoms in goats of the breed Saanen infected with worms was correlated with neutrophilia, which was not observed in the present study. Normal lymphocyte values were observed for the evaluated lambs (Table 4). A similar result was observed in another study of adult female sheep infected with GN (MARTINS et al., 2012).

Not many studies are available in the literature showing thrombogram data of sheep infected with worms. Therefore, new data to evaluate and describe controlled results in animals with haemonchosis are necessary. Thrombograms allow evaluating hemostasis disorders, contributing to the diagnosis and prognosis of different pathologies (FARIAS; BÓ, 2010). In this study, the thrombograms were similar between treatments and evaluation periods, with platelet averages ranging from 420 to $586\left(10^{3} /\right.$ $\mu \mathrm{L})$. Sevinc et al. (2013) reported platelet values $\left(512 \times 10^{3} / \mu \mathrm{L}\right)$, platelet distribution width (8.03), plateletcrit $(0.40 \%)$, and mean platelet volume (7.89 $\mathrm{fL})$ in healthy sheep.

In this study, animals with haemonchosis, at day zero of the experiments, showed hypoalbuminemia due to abomasitis, which reduces protein digestion, and therefore, the absorption of amino acids (BRICARELLO et al., 2004). Animals treated with $A$. blazei and trichlorfon recovered albumin levels after three weeks of treatment (Table 6). This regularization may be associated with FEC reduction (Table 1) and improvement of the abomasum mucosa. However, this needs to be confirmed in future studies. In contrast, animals with haemonchosis and untreated animals (control group) showed significant reduction in the serum concentration of albumin after the seventh day (Table 6) and an increase in the FEC mean (Table 1).

In cases of hyperacute haemonchosis, the animal may die suddenly because of severe hemorrhagic gastritis caused by the hematophagous action of the parasite. Moreover, hypoproteinemia and hypoalbuminemia may also occur (BRICARELLO et al., 2004). Sheep experimentally infected with $H$. contortus, treated with anthelmintic, and receiving selenium and vitamin E supplements, showed higher serum albumin than that by the group that received only supplements (NICOLODI et al., 2010). Sheep treated with different anthelmintics showed similar albumin concentrations among treatments and collection periods. However, a normalized albumin concentration at the twenty-fourth day posttreatment was observed only in the group treated with anthelmintic (HOLSBACK et al., 2013b).

In this study, the serum concentration of urea in lambs infected with haemonchosis was close to the lower reference limit for healthy sheep. The observed reduction might be constrained by a deficient protein metabolism as previously reported (BRICARELLO et al., 2004). The concentration of serum urea directly reflects the amount of protein nitrogen ingested or reduction in its absorption associated with injuries in the gastrointestinal mucosa (RIBEIRO et al., 2004).

\section{Conclusion}

Seven days after ingestion of A. blazei basidiocarp powder, the FEC of sheep infected with $H$. contortus significantly decreased, and after 21 days, the serum albumin concentration increased to normal values. Treatment with the fungus did not influence the blood parameters assessed, thus, suggesting that "mushroom of the sun" supplements may be a promising and complementary alternative in the treatment of haemonchosis.

\section{Acknowledgments}

The authors would like to acknowledge the Conselho Nacional de Desenvolvimento Científico e Tecnológico (CNPq) and the Fundação de Amparo à Pesquisa do Estado de Minas Gerais (FAPEMIG) for financial support. Support from the Pro-Reitorias de Pesquisa, Extensão e Graduação da Universidade Federal de Minas Gerais and the Laboratório de Patologia Clínica Labonorte ${ }^{\circledR}$ are also gratefully acknowledged. 


\section{References}

ALVES, P. H.; ARAÚJO, J. V.; GUIMARÃES, M. P.; ASSIS, R. C. L.; SARTI, P.; CAMPOS, A. K. Aplicação de formulação do fungo predador de nematoides Manacrosporium thaumasium (Drechesler, 1937) no controle de nematoides de bovinos. Arquivo Brasileiro Medicina Veterinária e Zootecnia, Belo Horizonte, v. 55, n. 5, p. 568-573, 2003.

AMARANTE, A. F. T.; SALES, R. O. Controle de endoparasitoses dos ovinos. Revista Brasileira de Higiene e Sanidade Animal, Fortaleza, v. 1, n. 2, p. 91113, 2007.

ASSOCIATION OF OFFICIAL ANALYTICAL CHEMIST - AOAC. Official Methods of Analysis. 15 $5^{\text {th }}$ ed. Washington, DC: AOAC, 1990. 1230p.

ARAÚJO, J. V.; RODRIGUES, M. L. A.; SILVA, W. W.; VIEIRA, L. S. Controle biológico de nematoides gastrintestinais de caprinos em clima semi-árido pelo fungo Monacrosporium thaumasium. Pesquisa Agropecuária Brasileira, Brasília, v. 42, n. 8, p. 11771181, 2007.

BIRGEL, D. B.; MULLER, A. F.; FANTINATO-NETO, P.; STORILLO, V. M.; BENESI, F. J.; BIRGEL JUNIOR, E. H. Avaliação do quadro eritrocitário e da repercussão do estado anêmico no leucograma de caprinos com verminose gastrointestinal. Pesquisa Veterinária Brasileira, Seropédica, v. 34, n. 3, p. 199-204, 2012.

BOWMAN, D. D. Georgis: parasitologia veterinária. 9. ed. Rio de Janeiro: Elsevier, 2010. 783 p.

BRICARELLO, P. A.; GENNARI, S. M.; OLIVEIRASEQUEIRA, T. C. G.; VAZ, C. M. S. L.; GONÇALVES DE GONÇALVES, I.; ECHEVARRIA, F. A. M. Worm burden and immunological responses in Corriedale and Crioula Lanada sheep following natural infection with Haemonchus contortus. Small Ruminant Research, Bloemfontein, v. 51, n. 1, p. 75-83, 2004.

BRUGGEMANN, R.; ORLANDI, J. M.; BENATI, F. J.; FACCIN, L. C.; MANTOVANI, M. S.; NOZAWA, C.; LINHARES, R. E. C. Antiviral activity of Agaricus blazei Murrill ss. Heinem extract against human and bovine herpesviruses in cell culture. Brazilian Journal of Microbiology, São Paulo, v. 37, n. 4, p. 561-565, 2006.

COLES, G. C.; BAUER, C.; BORGSTEEDE, F. H.; GEERTS, S.; KLEI, T. R.; TAYLOR, M. A.; WALLER, P. J. World Association for the Advancement of Veterinary Parasitology (WAAVP): methods for the detection of anthelmintic resistance in nematodes of veterinary importance. Veterinary Parasitology, Amsterdam, v. 44, n. 1, p. 35-44, 1992.
COSTA, K. M. F. M.; AHID, S. M. M.; VIEIRA, L. S.; VALE, A. M.; SOTO-BLANCO, B. Efeitos do tratamento com closantel e ivermectina na carga parasitária, no perfil hematológico e bioquímico sérico e no grau Famacha de ovinos infectados com nematódeos. Pesquisa Veterinária Brasileira, Seropédica, v. 31, n. 12. p. 1075-1082, 2011.

DIAS, E. S.; LABORY, C. R. G.; SILVA, R. Cultivo de cogumelos comestiveis. Lavras: Faepe-Universidade Federal de Lavras, 2002. 50 p.

FARIAS, M. G.; BÓ, S. D. Importância clínica e laboratorial do volume plaquetário médio. Jornal Brasileiro de Patologia e Medicina Laboratorial, Catete, v. 46, n. 4, p. 275-281, 2010.

HARVEY, J. W. Veterinary hematology: a diagnostic guide and color atlas. St. Louis, MO: Saunders/Elsevier, 2012. $384 \mathrm{p}$.

HOLSBACK, L.; MARQUEZ, E. S.; MENEGHEL, P. P. Resistência parasitária de helmintos gastrointestinais e avaliação dos parâmetros hematológicos de ovinos no norte do Paraná. Revista Brasileira de Medicina Veterinária, Rio de Janeiro, v. 35, n. 1, p. 76-84, 2013 b.

HOLSBACK, L.; PORTO, P. P.; MÁRQUEZ, E. S.; PORTO, E. P. Fito-bioterapia no controle de nematódeos gastrointestinais de ovinos. Semina: Ciências Agrárias, Londrina, v. 34, n. 6, p. 3841-3850, 2013a. Suplemento 2.

KEITH, R. K. The differentiation of infective larvae of some common nematode parasites of cattle. Australian Journal of Zoology, East Melbuorne, v. 2, n. 1, p. 223235, 1953.

LACERDA, R. M.; SOTO-BLANCO, B. Determinação das variantes de hemoglobina em ovinos mestiços Santa Inês. Revista Caatinga, Mossoró, v. 19, n. 4, p. 345-349, 2006.

MARTINS, M. F. M.; GARCIA, M.; CHATE, S. C.; TAVOLARI, F. A.; TEIXEIRA, R. B. C.; MERTENS JÚNIOR, L. R.; SILVA, M. M.; SCHEIBEL, M.; ABEL, L. J. Associação de imunoestimulante com anti-helmíntico no tratamento da verminose em ovinos. Ciência Rural, Santa Maria, v. 42, n. 12, p. 2229-2234, 2012.

MOLENTO, M. B.; VERÍSSIMO, C. J.; AMARANTE, A. T.; VAN WYK, J. A.; CHAGAS, A. C. S.; ARAÚJO, J. V.; BORGES, F. A. Alternativas para o controle de nematoides gastrintestinais de pequenos ruminantes. Revista Arquivos do Instituto Biológico, São Paulo, v. 80, n. 2, p. 253-263, 2013. 
NICOLODI, P. R. S. J.; CAMARGO, E. V.; ZENI, D.; ROCHA, R. X.; CYRILO, F. C.; SOUZA, F. N.; LIBERA, A. M. M. D.; BONDAN, C.; LEAL, M. L. R. Perfil protéico e metabolismo oxidativo de cordeiros experimentalmente infectados pelo Haemonchus contortus e suplementados com selênio e vitamina E. Ciência Rural, Santa Maria, v. 40, n. 3, p. 561-567, 2010.

NOVAES, M. R. C. G.; VALADARES, F.; REIS, M. C.; GONÇALVES, D. R.; MENEZES, M. C. The effects of dietary supplementation with Agaricales mushrooms and other medicinal fungI on breast cancer: Evidence-based medicine. Clinics, São Paulo, v. 66, n. 12, p. 2133-2139, 2006.

NATIONAL RESEARCH COUNCIL- NRC. Nutrients requirements of sheep. $2^{\text {th }}$ ed. Washington, DC: National Academies Press, 2007. 362 p.

PAYNE, J. M.; PAYNE, S. The metabolic profile test. Oxford: Oxford University Press, 1987. 192 p.

PUGH, D. G. Clínica de ovinos e caprinos. São Paulo: Roca, 2004. 501 p.

RIBEIRO, L. A. O.; MATTOS, R. C.; GONZALEZ, F. H. D.; WALD, V. B.; SILVA, M. A.; LA ROSA, L. V. Perfil metabólico de ovelhas Border Leicester x Texel durante a gestação e lactação. Revista Portuguesa de Ciências Veterinária, Lisboa, v. 99, n. 551, p. 155-159, 2004.

SAMPAIO, I. B. M. Estatística aplicada à experimentação animal. $3^{\text {td }}$ ed. Belo Horizonte: Fundação de Ensino e Pesquisa em Medicina Veterinária e Zootecnia, 2007. $265 \mathrm{p}$.

SEVINC, F.; SEVINC, M.; EKICI, O. D.; YILDIZ, R.; ISIK, N.; AYDOGDU, U. Babesia ovinos infections: detailed clinical and laboratory observations in the preand post-treatment períodos of fiels cases. Veterinary Parasitology, Amsterdam, v. 19, n. 1, p. 35-43, 2013.
SOCCOL, V. T.; SOTOMAIOR, C.; SOUZA, F. R.; CASTRO, E. A. Occurrence of resistance to anthelmintics in sheep in Paraná state, Brazil. Veterinary Record, Londres, v. 139, p. 421-422,1996.

SOTOMAIOR, C. S.; CARLI, L. M.; TANGLEICA, L.; KAIBER, B. K.; SOUZA, F. P. Identificação de ovinos e caprinos resistentes e susceptíveis a helmintos gastrintestinais. Revista Acadêmica Ciência Animal, São José dos Pinhais, v. 5, n. 4, p. 397-412, 2007.

UENO, H. Cultivo quantitativo de larvas de nematódeos gastrintestinais de ruminantes com tentativa para prédiagnóstico. El Salvador: JICA, 1995. 138 p.

VAL, C. H.; BRANT, F.; MIRANDA, A. S.; RODRIGUES, F. G.; OLIVEIRA, B. C. L.; SANTOS, E. A.; ASSIS, D. R. R.; ESPER, L.; SILVA, B. C.; RACHID, M. A.; TANOWITZ, H. B.; TEIXEIRA, A. L.; TEIXEIRA, M. M.; RÉGIS, W. C. B.; MACHADO, F. S. Effect of mushroom Agaricus blazei on immune response and development of experimental cerebral malária. Malaria Journal, Londres, v. 14, p. 311-323, 2015.

VALADARES, D. G.; DUARTE, M. C.; OLIVEIRA, J. S.; CHÁVEZ-FUMAGALLI, M. A.; MARTINS, V. T.; COSTA, L. E.; LETE, J. P. V.; SANTORO, M. M.; RÉGIS, W. C. B.; TAVARES, C. A. P.; COELHO, E. A. F. Leishmanicidal activity of the Agaricus blazei Murill in different Leishmania species. Parasitology International, Victoria, v. 60, n. 1, p. 1-7, 2011.

WHITLOCK, H. V. Some modifications of the MS Master helminth egg-counting technique and apparatus. Journal of the Council for Scientific and Industrial Research, Sidney, v. 21, p. 177-180, 1948. 
